\title{
Levels of anthocyanin, ßeta carotene and antioxidant activity of functional biscuits flour of purple, yellow and white fleshed sweet potatoes
}

\author{
ZAINAL ABIDIN ${ }^{1, \nu}$, LEWI JUTOMO ${ }^{2, v v}$, TITIK SRI HARINI ${ }^{1, v v v}$ \\ ${ }^{1}$ Faculty of Agriculture, Universitas Nusa Cendana, Jl. Adisucipto Kupang, East Nusa Tenggara, Indonesia. Telp./Fax. +62-380-881085. \\ "email: andyansyah1980@gmail.com,"v•titik_harini@yahoo.co.id. \\ ${ }^{2}$ Faculty of Public Health, Universitas Nusa Cendana Jl. Adisucipto Kupang, East Nusa Tenggara, Indonesia. Telp./Fax. +62-380-881090. \\ •vemail: lewi_2007@yahoo.com.
}

Manuscript received: 15 November 2018. Revision accepted: 20 May 2019.

\begin{abstract}
Abidin Z, Jutomo L, Harini TS. 2019. Levels of anthocyanin, Beta carotene and antioxidant activity of functional biscuits flour of purple, yellow and white-fleshed sweet potatoes. Trop Drylands 3: 22-28. Flour produced from sweet potato has the potentials to partly substitute wheat flour, which is relatively expensive in tropical regions such as Indonesia. This study aimed to determine the levels of anthocyanin, beta carotene and antioxidant activity of functional biscuit formulas based on flour of purple, yellow and white sweet potatoes from Sumba Barat Daya District, East Nusa Tenggara Province. The purple, yellow and white sweet potatoes were processed into flour then cooked into biscuits with varying mixing ingredients. The levels of anthocyanin, beta carotene and antioxidant activity were analyzed using UV-Visible Spectrophotometry. The results showed that the highest levels of biscuit anthocyanin (95.05 $\mathrm{ppm}$ ) was found in $75 \%$ purple sweet potato flour $+25 \%$ wheat flour formula. The highest beta carotene level of biscuit (10,190.44 $\mu \mathrm{g} / 100 \mathrm{~g}$ ) was found in $75 \%$ of yellow sweet potato flour $+25 \%$ flour formula. In biscuit products, the highest antioxidant activity $(61.57 \%)$ was found in the treatment of $75 \%$ purple sweet potato flour $+25 \%$ flour formula.
\end{abstract}

Keywords: Anthocyanin, antioxidant activity, beta carotene, biscuits

\section{INTRODUCTION}

Biscuits are well-known baked food products with good taste, sweet and crunchy texture. Biscuits are usually made from wheat flour, sugar and margarine. Yet, wheat flour is quite expensive in price, particularly in regions where wheat cultivation is not common such as in the wet tropics. Thus, substitute flour produced from raw materials that are locally grown is explored which can substitute wheat flour up to $50-75 \%$. One material that has the potential is sweet potato flour. Processed food products utilizing sweet potato flour as a partial substitute of wheat flour have no significant differences in chemical, physical and organoleptic properties as compared to those of wheat flour. Sweet potato flour can also be developed as a functional food.

Awareness of the importance of functional food has started to rise in early 1980, when many people of the world began to emphasize the choice of foods that can prevent health problems in the elderly and diseases related to lifestyles, such as diabetes, heart disease, high blood pressure, hypercholesterolemia, allergies, infectious diseases, and cancer. Food experts intensely promoted the third function of food, in addition to being a source of nutrition and enjoyment. This tertiary function modulates physiological control, known as 'biological regulatory function', in the immune system, glands, nerves, blood circulation, and digestion. The food must contain compounds that can activate this ability. These compounds are called 'functional factors'. Foods that contain a variety of functional factors and are processed for the purpose of providing a specific impact on health care are called 'functional foods' (Arai 2002).

Functional food is food that uses specific ingredients in its formulation because of its properties; hence, it contains several functional factors, among others is, antioxidant property. An antioxidant can remove free radicals that threaten healthy cells in the human body, leading to the development of cancer cells and endangering human health or causing degenerative diseases, which have not been well cured at the moment (Pietta 2000; Mukherjee and Mitra 2009).

Flour produced from purple, yellow and white sweet potatoes exhibits high antioxidant content as compared to other flour products. The antioxidants include anthocyanin, $\beta$-carotene, and other polyphenol compounds. Anthocyanin is known to be one of the groups of natural products found in plants that can act as antioxidants, antimicrobials, photoreceptors, visual attractors, feeding repellants, allergy, antiviral, and anti-inflammatory (Pietta 2000). Purple-fleshed sweet potato contains anthocyanin around \pm $519 \mathrm{mg} / 100 \mathrm{~g}$ weight (Kumalaningsih 2006). Yellow and white sweet potatoes contain Vitamin A of, respectively, 900 IS, and 7700 IS in the form of $\beta$-carotene. $\beta$-carotene is one of the carotenoids that can produce a higher amount of provitamin A than other types of carotenoids. Provitamin A is very easily absorbed by the digestive tract of the human gastrointestinal system which is then converted into vitamin A. 
Inappropriate implementation of sequestration technology and processing of functional food products as well as packaging and storage of the products can lead to reduced quantity and quality of antioxidants found in sweet potatoes. Processing of purple sweet potato will affect the anthocyanin level; for instance, $10-30 \%$ of anthocyanin damage did occur in the Ayamurasaki purple sweet potato varieties as a result of frying and steaming (Widjanarko 2008).

This study aimed to determine the levels of anthocyanin, beta carotene and antioxidant activity of functional biscuit formulas based on flour of purple, yellow and white sweet potatoes grown in Sumba Barat Daya District, East Nusa Tenggara Province, Indonesia.

\section{MATERIALS AND METHODS}

Fresh purple, yellow and white sweet potatoes were taken from Tena Teke Village, Wewewa Selatan Subdistrict, Sumba Barat Daya District, East Nusa Tenggara, Indonesia. Production of sweet potato flour and biscuit was carried out at Agricultural Post Harvest and Processing Laboratory, Faculty of Agriculture, Universitas Nusa Cendana, Kupang, Indonesia. Meanwhile, the chemical analysis of biscuits was carried out at the Pratama ChemMix Laboratory, Yogyakarta, Indonesia.

\section{The production process of purple, yellow and white sweet potato flour}

Sweet potato tubers collected in Sumba Barat Daya District were processed into sweet potato flour following the stages as presented in the flow-chart in Figure 1 while ingredients used in the production of biscuits are listed in Table 1.

Steps of production processes of biscuits from sweet potato flour are presented in Figure 2. Mixing of raw materials was carried out using the following steps: (i) The margarine was mixed with fine sugar using a mixer for two minutes until it turns white, (ii) Egg yolk was poured and mixed thoroughly with the above mixture (step 1), (iii) The flour was slowly poured and mixed with other materials then the mixture was squeeze

Sorting of sweet potato tuber

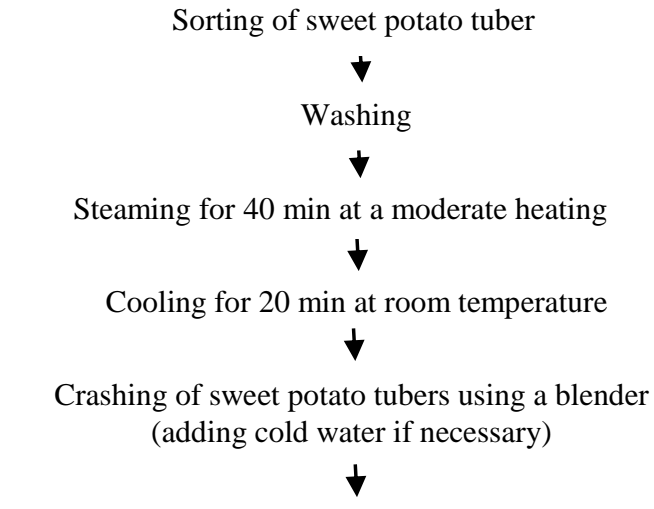

Pouring into plastic medium and drying under sunlight

Polishing using disk mill

Sieving using an 80-mesh sieve

Flour is packed into a thick plastic and used for the production of biscuits

Figure 1. Flowchart of sweet potato flour production

Table 1. Formulation of ingredients used to produce biscuits from sweet potato flour

\begin{tabular}{|c|c|c|c|c|c|c|}
\hline \multirow[t]{2}{*}{ Ingredient } & \multicolumn{6}{|c|}{ Treatment combination } \\
\hline & A1 (pspf) & A2 (pspf) & B1 (yspf) & B2 (yspf) & C1 (wspf) & C2 (wspf) \\
\hline Sweet potato flour & $50 \%(100 \mathrm{~g})$ & $75 \%(150 \mathrm{~g})$ & $50 \%(100 \mathrm{~g})$ & $75 \%(150 \mathrm{~g})$ & $50 \%(100 \mathrm{~g})$ & $75 \%(150 \mathrm{~g})$ \\
\hline Wheat flour & $50 \%(100 \mathrm{~g})$ & $25 \%(50 \mathrm{~g})$ & $50 \%(100 \mathrm{~g})$ & $25 \%(50 \mathrm{~g})$ & $50 \%(100 \mathrm{~g})$ & $25 \%(50 \mathrm{~g})$ \\
\hline Eggs & $60 \mathrm{~g}$ & $60 \mathrm{~g}$ & $60 \mathrm{~g}$ & $60 \mathrm{~g}$ & $60 \mathrm{~g}$ & $60 \mathrm{~g}$ \\
\hline Fine sugar & $60 \mathrm{~g}$ & $60 \mathrm{~g}$ & $60 \mathrm{~g}$ & $60 \mathrm{~g}$ & $60 \mathrm{~g}$ & $60 \mathrm{~g}$ \\
\hline Margarine & $50 \mathrm{~g}$ & $50 \mathrm{~g}$ & $50 \mathrm{~g}$ & $50 \mathrm{~g}$ & $50 \mathrm{~g}$ & $50 \mathrm{~g}$ \\
\hline Milk powder & $20 \mathrm{~g}$ & $20 \mathrm{~g}$ & $20 \mathrm{~g}$ & $20 \mathrm{~g}$ & $20 \mathrm{~g}$ & $20 \mathrm{~g}$ \\
\hline Baking powder & $1 \mathrm{~g}$ & $1 \mathrm{~g}$ & $1 \mathrm{~g}$ & $1 \mathrm{~g}$ & $1 \mathrm{~g}$ & $1 \mathrm{~g}$ \\
\hline
\end{tabular}

Note: $\mathrm{pspf}=$ purple sweet potato flour, $\mathrm{yspf}=$ yellow sweet potato flour, and wspf $=$ white sweet potato flour 

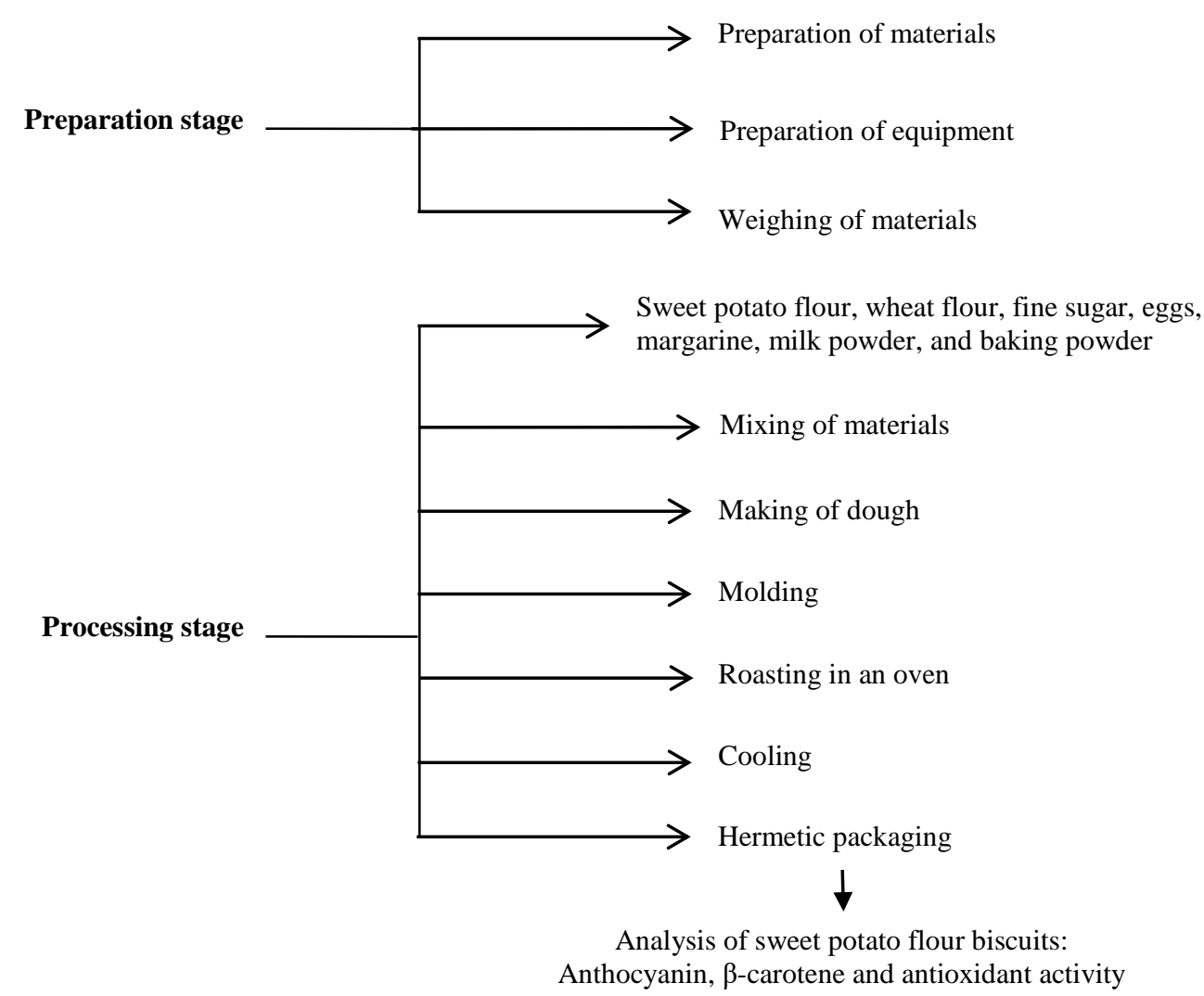

Figure 2. Flowchart of production processes of biscuits from sweet potato flour

well to produce elastic dough, (iv) The dough was flattened by using a wood roll tool to the same thickness. The dough was then printed using a biscuit mold and a hole was put on the top of the mold using a fork. The dough was then roasted in moderate heating for 10 minutes, (v) The biscuits were taken out from the oven and then cooled first to release the hot steam prior to packaging, (vi) Packaging: cooled biscuits were immediately packed using small stops or thick plastic to keep them remain crispy for an extended time and to maintain long-term shape.

\section{Analysis of anthocyanin content and antioxidant activity Extraction}

Extraction of the sweet potato flour was based on the method developed by Lee et al. (1998). Five grams of sweet potato flour were extracted five times each using 10 $\mathrm{mL}$ of $15 \%$ acetic acid in methanol for 30 minutes. The extraction was carried out using a shaker. The combined extract was then centrifuged at $12000 \mathrm{x}$ g for 10 minutes at room temperature. The supernatant was evaporated under vacuum at $40^{\circ} \mathrm{C}$ to make it dry. This dry extract was then dissolved in $25 \mathrm{~mL}$ methanol for further analysis.

\section{Total anthocyanin measurement}

Total anthocyanin measurement of the sweet potato flour was based on the method developed by Prior et al. (1998) and Giusti and Wroistad (2000): $0.05 \mathrm{~mL}$ sample was put into 2 test tubes. The first test tube was added with $4.95 \mathrm{~mL}$ potassium chloride $(0.025 \mathrm{M})$ buffer $(\mathrm{pH} 1.0)$ and the second test tube was added with $4.95 \mathrm{~mL}$ sodium acetate $(0.4 \mathrm{M})$ buffer $(\mathrm{pH} 4.5)$. The $\mathrm{pH}$ of potassium chloride and sodium acetate buffers was adjusted using concentrated $\mathrm{HCl}$. The two buffer solutions were kept at room temperature for 15 minutes, and the absorbance of the two was measured by using a spectrophotometer at a wavelength of $520 \mathrm{~nm}$ and $700 \mathrm{~nm}$. The absorbance value was calculated using the formula $\mathrm{A}=(\mathrm{A} 520-\mathrm{A} 700) \mathrm{pH} 1-$ (A520-A700) $\mathrm{pH}$ 4.5. Anthocyanin concentration was calculated as cyanidin-3-glycoside using a molar extraction coefficient of $29600 \mathrm{~L} / \mathrm{cm}$ and a molecular weight of 448.8. Anthocyanin concentration $(\mathrm{mg} / \mathrm{mL})=(\mathrm{A} \times \mathrm{BM} \times$ $\mathrm{FP} \times 1000) /(\mathrm{E} \times 1)$, where $\mathrm{A}$ is absorbance, $\mathrm{BM}$ is molecular weight (448.8). FP is a diluent factor $(5 \mathrm{~mL} / 0.05$ $\mathrm{mL})$, and $\mathrm{E}$ is an extra molar coefficient $(29600 \mathrm{~L} / \mathrm{cm})$. (iii) Measurement of antioxidant activity (Zambiazi et al. 2016). The DPPH radical scavenging activity (antioxidant activity) was determined by using the method described by Zambiazi et al. (2016) with some modifications. The extract solution was prepared by dissolving the extract at concentrations of 25, 50,100, 200, 400, 800 and $1000 \mathrm{ppm}$ in chloroform: methanol (2: 1). The extracts solution (4 $\mathrm{mL})$ in chloroform: methanol (2: 1) was mixed with $1 \mathrm{~mL}$ of DPPH (1,1-diphenyl-2-picrylhydrazyl) solution $0.2 \mathrm{mM}$ in methanol. The mixture was reacted or allowed to stand for 30 minutes before the absorbance showed an increase in DPPH radical capture ability. Uptake was measured by a UV-Vis spectrophotometer at a wavelength of $514 \mathrm{~nm}$. The DPPH radical scavenging activity as a percentage was then calculated as: 
DPPH scavenging activity $(\%)=100-\left(\mathrm{A}_{0}-\mathrm{A}_{1}\right) / \mathrm{A}_{0} \times 100$

Where

$\mathrm{A}_{0}=$ Absorbance from the control or without the addition of sample

$\mathrm{A}_{1}=$ Absorbance of sample

(iv) Analysis of Vitamin A content (Apriyanto 1989). Chloroform was washed using water in the same or 2-3 times volume, and then the water was released by using anhydrous potassium carbonate. Distillation was carried out, and a small amount (about 10\%) of initial distillate was removed. The antimony trichloride solution formed was washed with pure chloroform (water free) until it looked clear. The blank solution was prepared by evenly mixing $4 \mathrm{~mL}$ of antimony trichloride reagent and one $\mathrm{mL}$ of chloroform. $0.5 \mathrm{~mL}$ of the sample solution was then mix with $2 \mathrm{~mL}$ of antimony trichloride reagent. Absorbance of the solution was determined by using a spectrophotometer at a wavelength of $620 \mathrm{~nm}$. Vitamin A content was determined based on the standard curve (concentration of vitamin A acetate $0-15 \mathrm{mg} / \mathrm{mL}$ ).

\section{RESULTS AND DISCUSSION}

\section{The levels of Anthocyanin, $\beta$-carotene, free radical} scavenging activity of sweet potato flour-based biscuits

There was a substantial difference in the effect of antioxidant content and free radical scavenging capacity of the various treatments of biscuits produced from purple, yellow, and white sweet potatoes. The free radical scavenging activity of the treatments of sweet potato flourbased biscuits varied considerably as compared to that of sweet potato flour alone (Table 2).

Roasting of sweet potato flour-based biscuits at a temperature of $150-160^{\circ} \mathrm{C}$ for $20-30$ minutes tended to cause a decrease in the level of their anthocyanin contents as compared to that of the purple sweet potato flour alone. Table 2 shows a tendency of reduction of anthocyanin due to high-temperature roasting during the biscuits production processes. Anthocyanin level in biscuit products decreased from $229.03 \mathrm{ppm}$ (sweet potato flour alone) to, respectively, $95.05 \mathrm{ppm}$ in treatment $\mathrm{A} 1$ (58.50\%) and
$85.20 \mathrm{ppm}$ in treatment A2 $(62.80 \%)$. The decrease in anthocyanin levels was, presumably, caused by roasting in an oven or heating at a high temperature of $150^{\circ} \mathrm{C}$ for 20 30 minutes as extended exposure in high temperature can cause degradation of anthocyanin. This is supported by Abidin et al. (2016) who found that steaming with hot steam from boiling water for one hour in the making of steamed bolu under treatment of $90 \%$ purple sweet potato flour from Kupang District $+10 \%$ wheat flour formula produced an anthocyanin level of $19.11 \mathrm{ppm}$. Additionally, Sari et al. (2005) found that heating at $100^{\circ} \mathrm{C}$ for 4 hours could reduce the anthocyanin level by up to $80 \%$. Amr and Al-Tamimi (2007) found that $42 \%$ and $48 \%$ of Ranunculus asiaticus anthocyanins were lost after 7 hours of storage at $50{ }^{\circ} \mathrm{C}$ and $80^{\circ} \mathrm{C}$, respectively.

Antioxidant activity in purple sweet potato biscuit products decreased from $87.65 \%$ (purple sweet potato flour alone) to, respectively, $60.59 \%$ in treatment A1 (27.06\%) and $61.67 \%$ in treatment A2 $(25.98 \%)$. The decrease in antioxidant activity was, presumably, caused by the decline in anthocyanin levels. Tensiska et al. (2003) found that heating up to $175^{\circ} \mathrm{C}$ in an aqueous system for 2 hours reduced the activity of up to $17.4 \%$.

Additionally, in their study on osmo-dehydrated blueberries, Giovanelli et al. (2013) reported 50\% losses in antioxidant activity after processing. The loss was higher than that reported in the determined total anthocyanin and flavonoid contents. Contrastingly, the current study results showed that the most significant losses occurred in the phenolic compounds, flavonoids, and anthocyanins. According to Xiu-Li et al. (2015), the presence of hydroxyl groups in the anthocyanins molecule may contribute to the color instability caused by heating. Besides, the ringopening and degradation of anthocyanins were found to be the main factors responsible for the color change at high temperatures. Many studies indicated that the color stability of anthocyanins decreased during storage as temperature rises. The content of $\beta$-carotene of biscuit products increased significantly except for biscuits produced from yellow-fleshed sweet potato flour with a tendency to decrease in their $\beta$-carotene levels. The antioxidant activity of biscuits also tended to, although not significant (Figures 3 and 4).

Table 2. Levels of anthocyanin, $\beta$-carotene and free radical scavenging activity of biscuits produced from purple, yellow and whitefleshed sweet potato from Sumba Barat Daya District

\begin{tabular}{ccccc}
\hline Treatment & Biscuit formulation* & Anthocyanin $(\mathbf{p p m})$ & $\boldsymbol{\beta}$-carotene $(\boldsymbol{\mu g} / \mathbf{1 0 0}$ g) & $\begin{array}{c}\text { Free radical scavenging } \\
\text { activity }(\boldsymbol{\%})\end{array}$ \\
\hline A1 & $50 \%$ pspf+ 50\% wheat flour & 85.20 & $1,745.06$ & 60.59 \\
A2 & $75 \%$ pspf + 25\% wheat flour & 95.05 & $1,881.61$ & 61.57 \\
B1 & $50 \%$ yspf + 50 \% wheat flour & - & $9,670.82$ & 52.55 \\
B2 & $75 \%$ yspf + 25\% wheat flour & - & $10,190.44$ & 56.69 \\
C1 & $50 \%$ wspf + 50\% wheat flour & - & $1,197.59$ & 46.47 \\
C2 & $75 \%$ wspf + 25\% wheat flour & - & $1,301.18$ & 46.47 \\
pspf & - & 229.03 & 31.00 & 87.65 \\
yspf & - & - & $26,670.37$ & 86.86 \\
wspf & - & - & 16.77 & 84.51 \\
\hline
\end{tabular}

Note: pspf: purple sweet potato flour, yspf: yellow sweet potato flour, and wspf: white sweet potato flour; $\quad$-: unreadable tool 


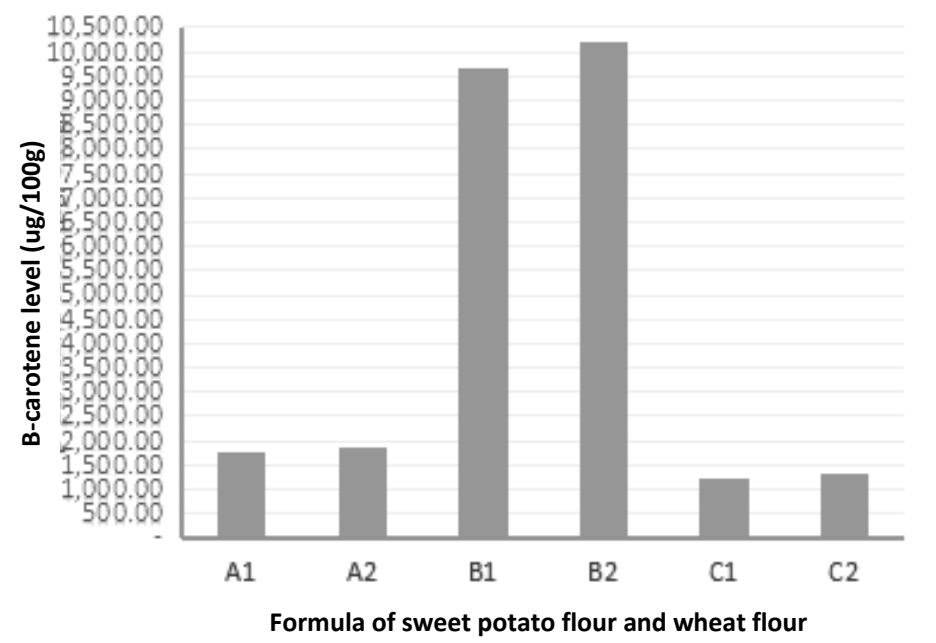

$A 1=50 \%$ purple sweet potato flour $+50 \%$ wheat flour $A 2=75 \%$ purple sweet potato flour $+25 \%$ wheat flour $B 1=50 \%$ yellow sweet potato flour $+50 \%$ wheat flour $B 2=75 \%$ yellow sweet potato flour $+25 \%$ wheat flour C1 $=50 \%$ wheat sweet potato flour $+50 \%$ wheat flour C2 $=75 \%$ wheat sweet potato flour $+25 \%$ wheat flour

Figure 3. The effect of roasting on $\beta$-carotene content of biscuits produced from purple, yellow and white sweet potatoes flour

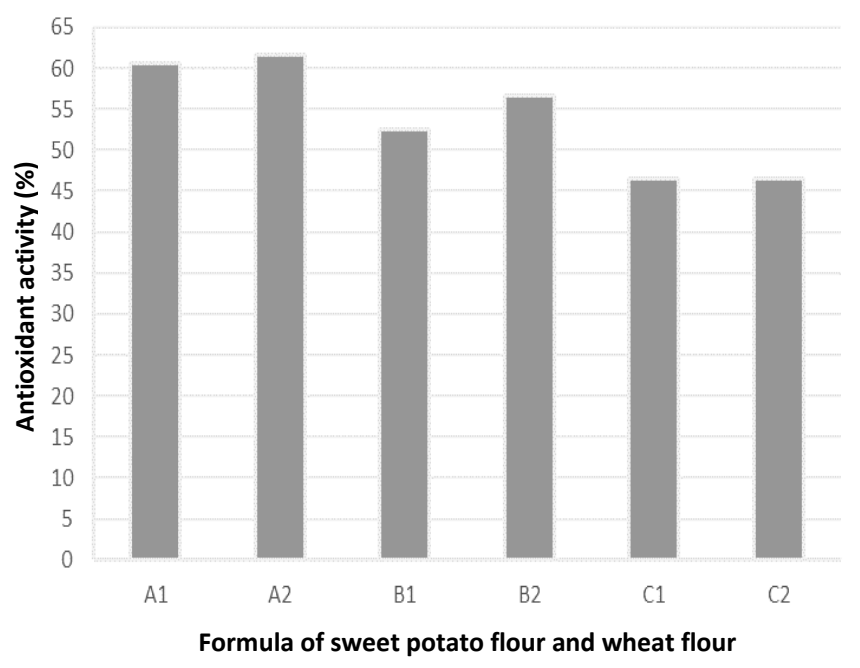

$A 1=50 \%$ purple sweet potato flour $+50 \%$ wheat flour $A 2=75 \%$ purple sweet potato flour $+25 \%$ wheat flour $\mathrm{B} 1=50 \%$ yellow sweet potato flour $+50 \%$ wheat flour $B 2=75 \%$ yellow sweet potato flour $+25 \%$ wheat flour C1 $=50 \%$ wheat sweet potato flour $+50 \%$ wheat flour C2 $=75 \%$ wheat sweet potato flour $+25 \%$ wheat flour

Figure 4. The effect of roasting on free radical (DPPH) scavenging capacity (antioxidant activity) of biscuits produced from purple, yellow and white sweet potatoes flour

It is demonstrated in Figure 3 that $\beta$-carotene levels significantly increased in biscuits produced from purple and white sweet potato flour as compared to that of plain purple and white sweet potato flour alone $(31 \mu \mathrm{g} / 100 \mathrm{~g}$ and $16.17 \mu \mathrm{g} / 100 \mathrm{~g})$. The increase of $\beta$-carotene levels was caused not only by additional $\beta$-carotene from sweet potato flour but also by the use of blue band butter in biscuit formulas. Butter contains natural antioxidants in the form of beta carotene of $30 \%$ (PT Unilever Indonesia 2018). $\beta$ carotene levels in biscuits produced from yellow sweet potato tended to decrease from $26670.37 \mu \mathrm{g} / 100 \mathrm{~g}$ (yellow sweet potato flour alone) to, respectively, $9670.82 \mu \mathrm{g} / 100 \mathrm{~g}$ in treatment B1 and $10190.44 \mu \mathrm{g} / 100 \mathrm{~g}$ in treatment B2. Biscuit products produced from yellow sweet potato flour experienced a decrease in $\beta$-carotene levels as the carotene was degraded by heating during roasting in the oven. Beta carotene level in yellow sweet potato flour-based biscuits was 40-47 times higher than that of purple and white sweet potato flour biscuits. Thus, yellow sweet potato flour can be used as one of the functional food ingredients. Yellow sweet potato contains a high $\beta$-carotene level. About $89 \%$ of total carotene in yellow sweet potato is in the form of $\beta$ carotene, $96.7 \%$ of which is dominated by the trans- $\beta$ carotene form (Sweeney and Marsh 1970; Woolfe 1992).

Additionally, Kurniawati and Ayustiningwarno (2012) stated that $\beta$-carotene content can be reduced and damaged due to processing. The existence of a double bond structure in $\beta$-carotene causes $\beta$-carotene to be easily oxidized when exposed to air $\left(\mathrm{O}_{2}\right)$. Erawati (2006) found that the oxidation process will take place more quickly in the presence of light, metal catalysts, and heating processes at high temperatures. This can result in a change in the trans- $\beta$ carotene structure to cis- $\beta$-carotene, where it has a lower provitamin A activity. Also, Lisia (2001) found that the 
content of $\beta$-carotene in yellow sweet potato flour was also reduced because of processing in bread making. Furthermore, Yusianti and Hariyadi (2001) also found that yellow sweet potato flour bread showed a decrease of $\beta$ carotene by $68.5 \%$ during roasting in an oven at $\pm 160^{\circ} \mathrm{C}$ for 15 minutes. The level of the reduction will be higher with increasing temperature and roasting time.

Vitamin $A$ is an essential nutrient that cannot be produced by the human body alone and is needed in limited quantities. Vitamin A possesses health benefits, i.e., in the process of vision, growth, reproduction and protecting cells and tissues from the effects of damaging free radicals leading to degenerative diseases (Mukherjee and Mitra 2009). Vitamin A deficiency may lead to fetal development abnormalities, anemia, weak immune function, rusting of the respiratory tract, and digestive tract, urinary tract, skin, and eye epithelium disorders (Mahan and Stump 2004). The effect of vitamin A deficiency is not detrimental at the beginning, but the untreated patient may suffer dusk blindness (xerophthalmia), where the sufferer is unable to see in the gloomy light. If this disease continues, it will cause the cornea to turn yellow, and a pattern appears on the cornea, which may cause the patient to suffer permanent blindness. Vitamin A deficiency in children may cause measles, respiratory infections, and diarrhea. The primary cause of vitamin A deficiency is a low intake of vitamin A-containing nutrients or vitamin A precursors that may not suffice the needs of vitamin $A$ in certain physiological and pathological conditions. Frequent suffering of diarrhea may also lead to low absorption of vitamin A.

It is depicted in Figure 4 that antioxidant activity or DPPH free radical scavenging activity of sweet potatobased biscuit products was high, ranging from 46.47$61.57 \%$. The free radicals scavenging activity in both products was generally higher than that of black rice from Ende, which ranged from 46.06-53.43\% (Lalel et al. 2009). The free radical scavenging activity is the most essential factor possessed by functional food. Free radicals originated from various sources such as pollutants or waste from the surrounding environment, food processing byproducts and motor vehicle and industrial pollution. These free radicals are very reactive to attack the molecules contained in the cell system, causing damage that cannot be repaired by the cells. Reactive oxygen species (ROS) damages lipids, proteins, enzymes, carbohydrates, and DNA in cell membranes leading to aging, heart disease, and cancer (Pietta 2000).

Sweet potato flour-based biscuits products are also considered functional foods as they contain functional factors. Antioxidant compounds in the form of anthocyanin and vitamin A contained in both products possess characters of chelating and preventing the effect of free radicals in the human body. Oxidation reactions are essentially chemical reactions that occur in the human body. The problem will arise from oxidation if the electron flow becomes unpaired resulting in free radicals including ROS such as superoxide $\left(\mathrm{O}_{2} *\right)$, peroxide $\left(\mathrm{ROO}^{*}\right)$, alkoxyl $\left(\mathrm{RO}^{*}\right)$, hydroxyl $\left(\mathrm{HO}^{*}\right)$ and nitric oxide (NO*). The very short half-life of free radicals such as hydroxyl (10-9 seconds) and alkoxyl (a few seconds) cause them to very reactive and rapidly attack molecules in nearby cells leading to unrepaired damage in the cell system. ROS can even be very damaging as it can attack lipids in cell membranes, tissue proteins or enzymes, carbohydrates, and DNA, causing damage to cell membranes, enzymes, and DNA. This oxidative reaction has been considered to play a role in the aging process, and various degenerative diseases such as heart attacks, cataracts, cognitive abilities dysfunction, and cancer (Pietta 2000).

$\beta$-carotene is an antioxidant, a provitamin $\mathrm{A}$ that is converted into vitamin A in the human body. It is highly beneficial for growth, maintenance of body tissues and vision, reproduction, fetal development, and reducing the risk of cancer and liver disease (Keller 2001).

To conclude, purple, yellow, and white sweet potatoes flour-based biscuits can be consumed as functional food. Biscuits produced from purple sweet potato contained $95.05 \mathrm{ppm}$ anthocyanin, $1881.61 \mu \mathrm{g} / 100 \mathrm{~g} \beta$-carotene and high free radical scavenging activity (61.57\%). Yellow sweet potato flour-based biscuits contained the highest $\beta$ carotene content $(10190.44 \mu \mathrm{g} / 100 \mathrm{~g})$ and free radicals scavenging ability of $56.69 \%$.

\section{ACKNOWLEDGEMENTS}

We want to thank Directorate General of Research and Community Services of Indonesian Ministry of Research, Technology and Higher Education for financially supporting this research through Strategic Nasional Institusi Research Scheme, 2018. The authors would also like to thank undergraduate students of Faculty of Agriculture, Universitas Nusa Cendana for their assistance, especially during the research activities in the Laboratory.

\section{REFERENCES}

Abidin Z, Jenny ER, Janet MY. 2016. Kajian substitusi parsial tepung terigu dengan tepung ubi jalar ungu terhadap mutu bolu kukus. Prosiding Seminar Nasional Pertanian. Universitas Nusa Cendana, Kupang, September 2016. [Indonesian]

Apriyantono A, Fardiaz D, Puspitasari NL, Sedarnawati, Budiyanto S. 1989. Petunjuk Laboratorium Analisis Pangan. PAU-IPB. Bogor. [Indonesian]

Amr A, Al-Tamimi E. 2007. Stability of the crude extracts of Ranunculus asiaticus anthocyanins and their use as food colourants. Int J Food Sci Technol 42 (8): 985-991. DOI: 10.1111/j.1365-2621.2006.01334.x.

Arai S. 2002. The functional food science initiation in Japan explores the boundary between food and medicine. Foods Food Ingredients J. Japan. 204:12-18

Erawati CM. 2006. Kendali stabilitas betakaroten selama proses produksi tepung ubi jalar (Ipomoea batatas L.). [Thesis]. Sekolah Pascasarjana Institut Pertanian Bogor. [Indonesian]

Giovanelli G, Brambilla A, Sinelli N. 2013. Effects of osmo-air dehydration treatments on chemical, antioxidant and morphological characteristics of blueberries. Food Sci Technol 54 (2): 577-584. DOI: 10.1016/j.lwt.2013.06.008

Giusti MM, Wroistad RE 2000. Characterization and Measurement of Anthocyanins by UV-Visible Spectrophotometry. John Wiley and Son Inc., New York. DOI: 10.1002/0471142913.faf0102s00

Keller H. 2001. National vitamin A supplementation campaign activities: August 2001. Crisis Bulletin. Year 3. Issue 2. September 2001. Helen Keller Int. Ind. Helen Keller International. 
Kumalaningsih S. 2006. Pengolahan Tepung Ubi Jalar Ungu. Trubus Agrisarana. Surabaya. [Indonesian]

Kurniawati, Ayustaningwarno F. 2012. Pengaruh substitusi tepung terigu dengan tepung tempe dan tepung ubi jalar kuning terhadap kadar protein, kadar $\beta$-karoten, dan mutu organoleptik roti manis. J Nutr Coll 1 (1): 344-351. http://ejournal-s1.undip.ac.id/index.php/jnc. DOI: 10.14710/jnc.v1i1.511 [Indonesian]

Lalel HJD, Abidin Z, Jutomo L. 2009. Karakterisasi dan pemanfaatan potensi antioksidan alami beberapa jenis padi gogo lokal Ende. Laporan Penelitian Hibah Bersaing. Faperta Undana Kupang. [Indonesian]

Lee HS, Oh SK, Choi HC, Kim SU. 1998. Identification of anthocyanins from pigmented rice seed. Agric Chem Biotechnol 41: 257-260.

Mahan K, Escott-Stump S. 2004. Krause's Food. Nutrition and Diet Therapy. Elsevier, USA.

Mukherjee S, Mitra A. 2009. Health effects of palm oil. J of Hum Ecol 26 (3); 197-203. DOI: 10.1080/09709274.2009.11906182

Pietta PG. 2000. Reviews: Flavonoids as antioxidants. J Nat Prod 63 : 1035-1042. DOI: 10.1021/np9904509

Prior RL, Cao G, Martin A, Sofic E, McEwen J, OBrien C, Lischner N, Ehlenfeldt M, Kaalt W, Krewer G, Mainland CM. 1998. Antioxidant capacity as influenced by total phenolic and anthocyanin content and maturity from Vaccinium species. J Agric Food Chem 46: 2686-2693. DOI: $10.1021 /$ jf $980145 \mathrm{~d}$

PT Unilever Indonesia. 2018. Blue Band serbaguna sumber omega 3 \& 6 dan 6 vitamin. Cikarang Bekasi 17520 Indonesia. https://www.blueband.co.id/produk/blueband-serbaguna/. [Indonesian]
Sari P, Agustina F, Komar M, Fauzi M, Lindriati T. 2005. Ekstraksi dan stabilitas antosianin dari kulit buah duwet (Syzygium cumini). J Teknol. Ind Pangan 16:142-150. [Indonesian]

Sweeney JP, Marsh AC. 1970. Vitamins and other nutrients. Separation of carotene stereoisomers in vegetables. JAOAC 53: 937-940. DOI: 10.1093/jaoac/53.5.937

Tensiska, Wijaya CH, Andarwulan S. 2003. Aktivitas antioksidan ekstrak buah andaliman (Zanthoxylum acanthopodium DC.) dalam beberapa sistem pangan dan kestabilan aktivitasnya terhadap kondisi suhu dan pH. J Teknol Ind Pangan 14: 29-39. [Indonesian]

Widjanarko SB. 2008. Efek Pengolahan terhadap Komposisi Kimia dan Fisik Ubi Jalar Ungu dan Kuning. Liberti, Yogyakarta. [Indonesian]

Woolfe JA. 1992. The Sweet Potato: An Untapped Food Resource. Cambridge University Press. England.

Xiu-li HE, Xue-li LI, Yuan-ping LV, Qiang HE. 2015. Composition and color stability of anthocyanin-based extract from purple sweet potato. Food Sci Technol Campinas 35 (3): 468-473. DOI: http://dx.doi.org/10.1590/1678-457X.6687.

Yusianti, L. 2001. Kajian formulasi dan proses pemanggangan roti kaya karotenoida dengan substitusi tepung ubi jalar dan minyak sawit. [Hon. Thesis]. Fakultas Teknologi Pertanian, Institut Pertanian Bogor. [Indonesian]

Zambiazi RC, Jansen C, Bueno-Costa MF, Silva SSD, Hartwig N. 2016. Bioactive compounds and antioxidant activity of blueberry toppings with honey. Int Food Res J 23 (6): 2375-2383. 